\title{
Pengaruh Metode Storytelling Berbantuan LCD Proyektor Terhadap Keterampilan Menyimak Dan Berbicara Peserta Didik SDN 64 Malaka Kabupaten Maros
}

\section{The Effect of Storytelling Method Assisted with LCD Projectors on Listening and Speaking Skills of Students in SDN 64 Malaka Maros Regency}

\author{
Hastuti $^{1}$, Muhammad Yunus ${ }^{2}$, Asdar $^{2}$ \\ ${ }^{1}$ Magister Pendidikan Dasar Program Pascasarjana, Universitas Bosowa \\ ${ }^{2}$ Program Studi Studi Pendidikan Dasar, Program Pascasarjana, Universitas Bosowa
}

E-mail: hastutimunsir22@gmail.com

Diterima: 10 Januari 2021/Disetujui 09 Juni 2021

\begin{abstract}
Abstrak. Penelitian ini bertujuan, untuk mengetahui: (1) pengaruh penerapan metode story telling berbantuan LCD proyektor terhadap keterampilan menyimak peserta didik SDN 64 Malaka Kabupaten Maros, (2) pengaruh penerapan metode story telling berbantuan LCD proyektor terhadap keterampilan berbicara peserta didik SDN 64 Malaka Maros, dan (3) pengaruh penerapan metode storytelling berbantuan LCD proyektor terhadap keterampilan menyimak, dan keterampilan berbicara secara terpadu peserta didik SDN 64 Malaka Kabupaten Maros. Subjek penelitian ini, adalah peserta didik kelas V SDN 64 Malaka semester I tahun ajaran 2020/2021 dengan jumlah peserta didik 19 orang yang terdiri atas 11 orang laki-laki dan 8 orang perempuan. Hasil penelitian menunjukkan bahwa, metode story telling berbantuan proyektor dapat berpengaruh terhadap keterampilan menyimak, keterampilan berbicara, dan keterampilan menyimak dan berbicara secara terpadu. Hal ini dibuktikan, dengan adanya nilai pos test pada peserta didik, nilai ketuntasan belajar nilai postest keterampilan menyimak $72,11 \%$ yang sebelumnya pada pelaksanaan pretest (tes awal) hanya sebesar $66,63 \%$, nilai ketuntasan belajar nilai postest keterampilan berbicara $73,53 \%$ yang sebelumnya pada pelaksanaan pretest (tes awal) hanya sebesar $64,11 \%$, nilai ketuntasan belajar nilai postest keterampilan menyimak dan berbicara secara terpadu $75,95 \%$ yang sebelumnya pada pelaksanaan pretest (tes awal) hanya sebesar $68,42 \%$. Dengan demikian, metode story telling berbantuan LCD proyektor dapat berpengaruh terhadap nilai keterampilan menyimak, keterampilan berbicara, dan keterampilan menyimak, dan keterampilan berbicara secara terpadu.
\end{abstract}

Kata Kunci: Keterampilan Menyimak, Keterampilan Berbicara, Metode Storytelling, LCD Proyektor

\begin{abstract}
This study aims to determine:(1) the effect of the implementation of storytelling method assisted with LCD projectors on the listening skill of students in SDN 64 Malacca, Maros Regency, (2) the effect of the implementation of storytelling method assisted with LCD projectors on the speaking skill of students in SDN 64 Malacca, Maros Regency, and ( 3) the effect of the implementation of storytelling method assisted with LCD projectors on listening and speaking skills of students simultanously in SDN 64 Malaka, Maros Regency. The subjects of this studying were students in grade V SDN 64 Malacca in the first semester of 2020/2021 school year with 19 students consisting of 11 boys, and 8 girls. The results showed that the projector-assisted storytelling method can affect listening skill, speaking skill, and listening and speaking skills in an integrated manner. This is evidenced by the presence of post-test scores of students. Post-test score for listening skill was $72.11 \%$ while previously in the pre-test it was only $66.63 \%$. Post-test score for speaking skill was $73.53 \%$ while previously in the pre-test it was only $64.11 \%$. The posttest value of listening and speaking skills in an integrated manner was $75.95 \%$ while previously in the pretest it was only $68.42 \%$. Thus, the LCD projector-assisted story telling method can affect the scores of listening skill, speaking skill, listening and speaking skills in an integrated manner.
\end{abstract}

Keywords: Listening Skill, Speaking Skill, Storytelling Methods, LCD Projector

\section{Pendahuluan}

Pendidikan nasional, berakar pada kebudayaan bangsa Indonesia berdasarkan pada Pancasila dan Undang-Undang Dasar 1945. Undang-Undang Dasar 1945 mengamanaatkan upaya mencerdaskan kehidupan bangsa serta agar pemerintah mengusahakan, dan menyelenggarakan satu sistem dalam pengajaran nasional yang diatur dengan undang- undang. Pendidikan dasar, adalah bagian bagian terpadu dari sistem pendidikan nasional. Pendidikan daasar merupakan pendidikan yang lamanya sembilan tahun diselenggarakan selama 6 tahun di sekolah dasar dan tiga tahun di sekolah lanjutan tingkat pertama atau satuan pendidikan yang sederajat (Majid, 2014).

Bahasa merupakan alat komunikasi, untuk menyampaikan gagasan, pesan, dan informasi yang tertanam dalam pikiran, media penyampaiannya, bisa melalui lisan atau tulisan. Bahasa juga memiliki peran sentral, demi terciptanya masyarakat yang santun, dserta beradab (Jainuddin dkk, 2020). Seseorang dikatakan santun atau tidak, ditentukan oleh sikap berbahasanya meliputi nada dan makna yang disampaikan. Berbagai kebudayaan bisa saling menyatu, karena ada salah satu 
aspek yang mampu mengingatnya yaitu bahasa. Pembelajaran bahasa Indonesia, saat ini telah menncakup seluruh aspek kebahasaan, maka siswa dituntut mampu berkomunikasi secara efektif, selalu menggunakan bahasa indonesia sebagai alat komunikasi formal, memahami bahasa indonesia, dan menggunakannya dengan tepat, serta mampu membanggakan bahasa indonesia sebagai budaya indonesia. Dengan begitu, siswa mampu menggunakan bahasa Indonesia dengan di sertai rasa bangga terhadap budayanya sendiri.

Sesuai kedudukan bahasa Indonesia, sebagai bahasa nasional, dan bahasa negara, maka kegunaan mata pelajaran bahasa serta sastra Indonesia yaitu: (a) sarana serta pembinaan kesatuan, sertapersatuan bangsa, (b) sarana peningkatan pengetahuan, dan keterampilan berbahasa indonesia, dalam rangka pelestarian danpengembangan budaya, (c) sarana peningkatan, dan keterampilan bahasa Indonesia untuk meraih, dan mengembangkan ilmu pengetahuan, teknologi, dan seni, (d) sarana penyebarluasan cara pemakaian bahasa indonesia yang baik, untuk berbagai keperluan menyangkut berbagai masalah, (e) sarana pengembang penalaran, (f) sarana pemahaman beraneka ragam budaya indonesia, melalui khazanah, kesusastraan Indonesia (Depdiknas, 2003).

Keterampilan berbahasa, meliputi keterampilan berbicara, menyimak membaca, dan menulis. Keterampilan berbicara, dan menulis bersifat ekspresif atau produktif yaitu memberikan informasi, sedangkan keterampilan menyimak, dan membaca bersifat reseftif yaitu meenerima informasi.

Menurut Hardini dan Pupitasari (dalam Deliadan Elvina (2019), keterampilan menyimak, adalah satu bentukketerampilan berbahasa, yang bersifat reseptif. Selanjutnya, menurut Krimah dalam Delia dan Elvina (2019) keterampilan menyimak pada awal kehidupan manusia, lebih dulu belajar menyimak, setelah berbicara, kemudian membaca, dan menulis. Menurut Jainuddin (2019) Penguasaan keterampilan menyimak, berpengaruh pada keterampilan berbahasa lain.

Keterampilan menyimak siswa sangat berpengaruh pada keterampilan berbicara, membaca, dan menulis. Tanpa menguasai keterampilan menyimak siswa, tidak mampu berbicara. Pentingnya menyimak, dalam interaksi komunikatif, memang sangat nyata. Supaya dapat terlibat dalam suatu komunikasi, seseorang harus mampu memahami, serta mereaksi yang baru saja dikatakan. Konsekuensinya pembelajaran perlu melatih keterampilan menyiimak, anak bisa memperoleh kosa kata, dan gramatikal, disamping itu tentunya pengucapannya yang baik. Dengan demikian, kegiatan menyimak, perlu dipusatkan, serta dikembangkan sedini mungkin, karena sebagai dasar pengembangan kemampuan berbahasa lainnya (Aziees dan Alwasih, 2000).

Keterampilan berbicara, penting mempermudah berkomunikasi dengan orang lain. Keterampilan berbicara yang sangat terbatas (tidak terampil), akan menggangu kelangsungan proses berkomunikasi antara pemberi pesan, dan penyimak (orang yang menerima informasi), dengan berbicara yang baik, serta benar maka maksud pesan yang ingin disampaikan pemberi pesan, dapat diterima dengan baik oleh si penyimak.

Pemberi pesan, dan penyimak sama-sama dituntut memilik keterampilan berbicara yang baiksupaya komunikasi terjalin dengan baik. Komunikasi merupakan sesuatu yang fungsional, mengandung maksud, dirancang untuk menghasilkan beberapa efek / akibat pada lingkungan para pembicara, dan penyimak (Henry, 2008). Kegiatan menyimak menjadi lebih mudah, bila penyimak mengetahui pesan yang ingin disampaikan oleh pemberi pesan (pembicara). Penyimak dituntut untuk memusatkan perhatian supaya dapat meemahami pesan yang terkandung. Penyimak terlebih dahulu harus berkonsentrasi menyimak informasi disampaikan, kemudian dipahami maksud pesan diberikan pembicara.

Menurut Hidayat dalam Rahayu (2013) storytelling atau bercerita merupakan aktivitas menuturkan sesuatu mengisahkan tentang perbuatan, pengalaman baik kejadian sungguh- sungguh terjadi maupun hasil rekaan. Kegiatan bercerita juga menambah kemampuan berbahasa anak, membantu mereka menginternalisasi karakter cerita. Metode story telling dalam belajar dan pembelajaran memungkinkan peserta didik untuk dapat melatih keterampilan menyimak, serta berbicara, peserta didik lebih aktif dalam mengikuti belajar dan pembelajaran di kelas, berani mengemukakan pendapat. Dengan demikian, peserta didik menjadi lebih untuk percaya diri, baik dalam proses pembelajaran, maupun dalam berinteraksi dan lingkungannya yang menuntut harus terampil berbicara. Hal tersebut sangat cocok diterapkan, di SDN Desa Cenrana Baru Kecamatan Cenrana.

Berdasarkan hasil observasi awal yang dilakukan peneliti, yang pernah dilakukan (Arianto, 2018) faktor menyebabkan hasil belajar pembelajaran bahasa indonesia khususnya aspek menyimak, berbicara rendah umumnya adalah rendahnya kemampuan siswa, dalam memahami materi pembelajaran, kurangnya kemampuan siswa dalam mengungkapkan kembali hasil simakannya melalui berbicara, motivasi belajar siswa rendah. Hal ini disebabkan oleh belum optimalnya usaha, dilakukan guru untuk membantu kesulitan belajar siswa, kurangnya variasi metodemengajar yang digunakan guru memotivasi belajar siswa di kelas. Peserta didik saat menyimak bacaan, yang dibacakan guru hanya untuk mengantuk dan bosan bahkan peserta didik, kadang malu / ragu-ragu, setelah guru memberikan kesempatan, untuk berbicara, menceritakan ulang, tentang materi yang disimak dari bacaan, yang dibacakan guru.

Oleh karena itu, guru harus menggunakan metode tidak membosankan, karena guru hanya menggunakanmetode ceramah, sehingga anak- anak merasa bosan dan tidak tertarik untuk belajar. Dan masih jarang menggunakan metode storytelling, berbantuan LCD proyektor. Metode story telling berbantuan LCD proyektor baik digunakan, dalam pembelajaran bahasa indonesia materi aspek keterampilan menyimak, berbicara karena peserta didik akan terfokus, tidak bosan dan mengantuk.

Penelitian dilakukan ini sangat penting sebagai proses pembelajaran menyeenangkan, dan tidak membosankan yang di mana dilakukan dengan cara menggunakan metode storytelling berbantuan LCD proyektor oleh sebab itu pembelajaran, di dalam kelas, tidak bisa lepas dari bantuan metode, media dan alat peraga pembelajaran, agar peserta didik dapat lebih aktif dan terfokus dalam pembelajaran yang berlangsung. Oleh sebab itu peneliti memilih, judul, Pengaruh metode storytelling berbantuan proyektor terhadap KeterampilanMenyimak, dan Berbicara peserta didik di SDN 64 Malaka Kabupaten Maros. 
Peneliti melakukan penelitian ini, dengan harapan, dapat memperbaiki pembelajaran Bahasa indonesia khususnya aspek keterampilan berbahasa, yang dapat memberikan pengaruh, terhadap pembelajaran keterampilan menyimak, serta berbicara yang dianggap belum optimal.

\section{Metode Penelitian}

Jenis penelitian ini adalah penelitian eksprimen. Penelitian dengan pendekatan eksperimenyakni suatu penelitian, yang berusaha mencari pengaruh variabel tertentu, terhadap variabel yang lain dalam kondisi yang terkontrol secara ketat (Riduwan, 2018). Penelitian eksprimen adalah metode penelitian yang digunakan,untuk mencari pengaruh perlakuan teertentu terhadap yang lain, dalam kondisi yang sangat terkendali, (Sugiono, 2013). Penelitian ini juga menggunakan PreExperimental Design dengan bentuk One-Group Pretest- Post test Design, yang di dalam desain ini ada pretest sebelum diberikan perlakuan. Dengan demikian, hasil perlakuan, dapat diketahui lebih akurat karena dapat membandingkan, dengan keadaan sebelum, diberi perlakuan. Desain ini dapat digambarkan seperti berikut:

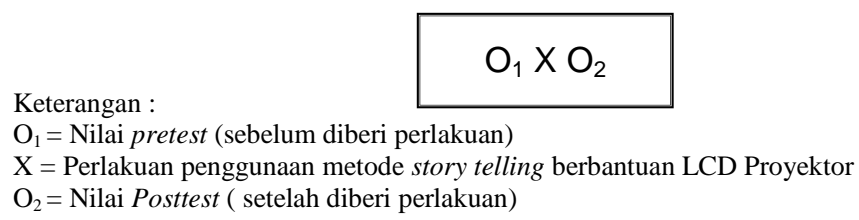

Gambar 1 Desain Penelitian One- Group Pretest- Postest Design (Sugiyono, 2013)

Penelitian dilaksanakan di Desa Cenrana Baru terletak di Kecamatan Cenrana, Kabupaten Maros. Di SDN 64 Malaka Kabupaten Maros memiliki letak yang sangat strategis, karena berada di dalam daerah padat penduduk sertamudah dijangkau dari berbagai arah. Variabel penelitian ini dari pendapat para ahli, dapat disimpulkan adalah segala sesuatu hal yang ditentukan, dan di tetapkan peneliti untuk menjadi obyek peneliti sehingga dapat di pelajari, di tarik kesimpulan oleh peneliti. Variabel peneliti terdiri dari bermacam - macam, di antaranya yaitu: variabel independen, dependent, moderator, intervening, dan variabel control. Pada penelitian ini variabeli dibahas adalah variabel independen ( bebas ) dan pariabel dependen ( terikat ).

Teknik pengumpulan data digunakan adalah teknik tes dan non-tes. Teknik tes digunakan adalah untuk mengukur keterampilan menyimak, peserta didik berupa soal uraian. Sedangkan teknik non-tes berupa aspek penilaian berbicara serta keterampilan berbicara secara terpadu denga $\mathrm{n}$ menggunakan angket. Instrument penelitian yang digunakan dalam penelitian ini yaitu instrument tes serta non tes. Instrumen tes yang digunakan untuk mengetahui data tentang keterampilan menyimak. Bentuk instrument non tes, dalam penelitian ini digunakan supaya mengetahui keterampilan berbicara, keterampilan menyimak serta berbicara secara terpadu.

\section{Hasil dan Pembahasan}

Hasil penelitian yang dilaksanakan di SDN 64 Malaka dengan subjek penelitian sebanyak 19 peserta didik, mengenai pengaruh metode story telling berbantuan LCD proyektor terhadap keterampilan menyimak, serta berbicara. Data hasil penelitian adalah data yang dihasilkan dari data nilai pre - test dan pos- test. Hasil penelitian ini diuraikan ke dalam 3 gambaran, yakni: Pengaruh Penerapan metode story telling berbantuan proyektor terhadap keterampilan menyimak peserta didik SDN 64 Malaka

Pada sub bagian ini akan menjawab rumusan masalah yaitu pengaruh penerapan metode story telling berbantuan proyeektor terhadap keterampilan menyimak peserta didik SDN 64 Malaka. Untuk mengetahui apakah ada pengaruh signifikan terhadap keterampilan menyimak, setelah meenggunakan metode storytelling berbantuan LCD proyektor. Analis yang digunakan adalah analisis statistik, inferensial. Analisis statistik infeerensial, dalam menguji hipotesis, maka diperlukan pengujian dasar terlebih dahulu yaitu uji normalitas, dan uji homogenitas. Uji hipoteesis dilakukan setelah data dari tes keterampilan menyimak terkumpul. Dalam penelitian ini, uji hipootesis menggunakan uji paired sample T-test, dengan bantuan SPSS Versi 25 for windows. Uji paaired sample T-test digunakan untuk mengetahui ada pengaruh yang signifikan atau tidak.

Uji hiipotesis paired sample t- test dimana jika Asymptotic Sig. < 5\% $(0,05)$ yang artinya ada pengaruuh penggunaan metode storytelling berbantuan LCD proyektor terhadap keterampilan meenyimak peserta didik SDN 64 Malaka.

Tabel 1. Hasil Uji Hipotesis Keterampilan Menyimak Paired Sample T-test

\begin{tabular}{|c|c|c|c|c|c|c|c|c|c|}
\hline \multicolumn{10}{|c|}{ Paired Samples Test } \\
\hline \multicolumn{10}{|c|}{ Paired Differences } \\
\hline & & \multirow{2}{*}{ Mean } & \multirow{2}{*}{$\begin{array}{l}\text { Std. } \\
\text { Deviation }\end{array}$} & \multirow{2}{*}{$\begin{array}{l}\text { Std. Error } \\
\text { Mean }\end{array}$} & \multicolumn{2}{|c|}{$\begin{array}{l}\text { 95\% Confidence Interval of the } \\
\text { Difference }\end{array}$} & \multirow[t]{2}{*}{$\mathrm{T}$} & df & \multirow[t]{2}{*}{$\begin{array}{l}\text { Sig. }(2- \\
\text { tailed) }\end{array}$} \\
\hline & & & & & Lower & Upper & & & \\
\hline $\begin{array}{l}\text { Pair } \\
1\end{array}$ & $\begin{array}{l}\text { Nilai_Pretest_Ket._Menyimak - } \\
\text { Nilai_Postest_Ket._Menyimak }\end{array}$ & -5.474 & 2.118 & .486 & -6.494 & -4.453 & -11.266 & 18 & .000 \\
\hline
\end{tabular}

Sumber: Hubungan antara Nilai Pre -test dan Pos-test Keterampilan Menyimak 
Berdasarkan Tabel 4 diketahui bahwa nilai Asymptootic Sig sebesar 0,000 yang artinya kurang dari Sig alpha yang di tentukan yaitu $5 \%(0,05)$ maka ada peengaruh yang signifikan dengan penggunaan metode story telling berbantuan LCD proyektor, terhadap keterampilan menyimak peserta didik.

Tabel 2 Hasil Uji Hipotesis Keterampilan Menyimak Paired Sample Statistic

\begin{tabular}{llrrrr}
\hline & Paired Samples Statistics & & & \\
\hline & Mean & N & Std. Deviation & Std. Error Mean \\
\hline Pair 1 & Nilai_Pretest_Ket._Menyimak & 66.63 & 19 & 5.795 & 1.329 \\
& Nilai_Postest_Ket._Menyimak & 72.11 & 19 & 6.136 & 1.408 \\
\hline Sumber: Hasil Ringkasan Statistik Keterampilan Menyimak & & &
\end{tabular}

Berdasarkan tabel 5 di perlihatkan hasil ringkaasan statistik dari kedua sampel atau daata pre-test dan pos-test. Nilai rata- rata pre- test keterampilan menyimak yakni 66.63 lebih kecil dari nilai raata- rata pos -test keteraampilan menyimak yakni 72.11 dengan juumlah responden atau peserta didik dijadikan sampel sebanyak 19 peserta didik. Hal ini mengindikasikan bahwa penerapan metode story telling berbantuan LCD proyektor secara baik, sertabenar berpengaruh terhadap keterampilan menyimak peserta didik.

a. Pengaruh Penerapan metode storytelling berbantuan proyektor terhadap keterampilan berbicara peserta didik SDN 64 Malaka

Pada sub bagian ini akan menjawab rumusan masalah yaitu Pengaruh Penerapan metode story telling beerbantuan proyektor terhadap keterampilan berbicara peserta didik SDN 64 Malaka. Untuk mengetahui apakah ada pengaruh signifikan terhadap keterampilan berbicara setelaah menggunakan metode storytelling berbantuan LCD proyektor. Analis yang digunakan adaalah analisis statistik inferensial. Analisis statiistik infeerensial, dalam menguji hipotesis, maka diperlukan pengujian dasar, terlebih dahulu yaitu uuji normalitas dan uji homogenitas. Uji hipotesis di lakukan setelaah data dari tes keterampilan berbicara terkumpul., Dalam penelitian ini, uji hipotesis menggunakan uji paired sample T-test dengan bantuan SPSS Versi 25 for windows. Uji paired sample T-test di gunaakan supaya mengetahui ada pengaruh yang signifikan atau tidak.

Uji hipotesis paired sample t-test dimana jika Asymptotic Sig. $<5 \%(0,05)$ yang artinya ada pengaruh penggunaan metode story tellingberbantuan LCD proyektor terhadap keterampilan ber bicara ,peserta didik SDN 64 Malaka.

Tabel 3 Hasil Uji Hipotesis Keterampilan Berbicara Paired Sample T-test

\section{Paired Samples Test}

Paired Differences

\begin{tabular}{|c|c|c|c|c|c|c|c|c|c|}
\hline & & \multirow[b]{2}{*}{ Mean } & \multirow[b]{2}{*}{ Std. Deviation } & \multirow{2}{*}{$\begin{array}{l}\text { Std. Error } \\
\text { Mean }\end{array}$} & \multicolumn{2}{|c|}{$\begin{array}{l}\text { 95\% Confidence Interval } \\
\text { of the Difference }\end{array}$} & \multirow[b]{2}{*}{$\mathrm{T}$} & \multirow[b]{2}{*}{ df } & \multirow{2}{*}{$\begin{array}{l}\text { Sig. }(2- \\
\text { tailed) }\end{array}$} \\
\hline & & & & & Lower & Upper & & & \\
\hline Pair 1 & $\begin{array}{l}\text { Nilai_Pretest_Keterampilan_Berbicara - } \\
\text { Nilai_Postest_Keterampilan_Berbicara }\end{array}$ & -9.421 & 3.717 & .853 & -11.212 & -7.630 & -11.049 & 18 & .000 \\
\hline
\end{tabular}

Sumber: Hubungan antara Nilai Pre-test dan Pos-test Keterampilan Berbicara

Berdasarkan tabel 3 di ketahui, bahwa nilai Asymptotic Sig sebesar 0,000, yang artinya kurang dari Sig alpha yang ditentukan yaitu $5 \%(0,05)$ maka ada pengaruh yang signifikan dengan penggunaan metode storytelling, berbantuan proyektor terhadap keterampilan berbicara, peserta didik.

Tabel 4. Hasil Uji Hipotesis Keterampilan BerbicaraPaired Sample Statistik

\begin{tabular}{llccccc}
\hline & & Paired Samples Statistics & & & \\
& & Mean & N & Std. Deviation & Std. Error Mean \\
\hline Pair 1 & Nilai_Pretest_Keterampilan_Berbicara & 64.11 & 19 & 6.557 & 1.504 \\
& Nilai_Postest_Keterampilan_Berbicara & 73.53 & 19 & 6.059 & 1.390 \\
\hline
\end{tabular}

Sumber: Hasil Ringkasan Statistik Keterampilan Berbicara

Berdasarkan Tabel 4, diperlihatkan hasil ringkasan statistik, dari kedua sampel atau data pre-test dan pos-test. Nilai rata-rata pre -test keterampilan menyimak yakni 64.11 lebih kecil dari nilai rata-rata, pos-test keterampilan menyimak, yakni 73.53 dengan jumlah responden, atau peserta didik dijadikan sampel sebanyak 19 peserta didik. Hal ini mengindikasikan bahwa penerapan metode storytelling, berbantuan LCD proyektor secara baik serta benar, berpengaruh terhadap keterampilan berbicara peserta didik.

b. $\quad$ Pengaruh Penerapan metode storytelling berbantuan proyektor terhadap keterampilan menyimak dan berbicara secara terpadu terhadap peserta didik SDN 64 Malaka

Pada sub bagian ini akan menjawab rumusan masalah, yaitu Pengaruh Penerapan metode story telling berbantuan proyek torterhadap keterampilan menyimak dan berbicara secara terpadu terhadap peserta didik, SDN 64 Malaka. Untuk mengetahui apakah ada pengaruh signifikan terhadap keterampilan menyimak, serta berbicara secara terpadu setelah menggunakan metode storytelling berbantuan LCD proyektor. Analis yang digunakan adalah analisis statistik, inferensial. Analisis statistik inferensial dalam menguji hipotesis, maka diperlukan pengujian dasar, terlebih dahulu yaitu uji normalitas dan uji homogenitas. Uji hipotesis dilakukan setelah data dari tes keterampilan menyimak dan beerbicara secara terpadu 
terkumpul. Dalam penelitian ini, uji hipotesis menggunakan uji paired sample T-test dengan bantuan SPSS Versi 25 for windows. Uji paired sample T-test digunakan untuk mengetahui ada pengaruh yang signifikan atau tidak.

Uji hipotesis paired sample t-test dimana jika Asymptotic Sig. $<5 \%(0,05)$ yang artinya ada pengaruh penggunaan metode story tellingberbantuan LCD proyektor terhadap keeterampilan menyimak sertaberbicara secara terpadu peserta didik SDN 64 Malaka.

Tabel 5 Hasil Uji Hipotesis Keterampilan Menyimak dan Berbicara Secara TerpaduPaired Sample T-test

Paired Samples Test

Paired Differences

\begin{tabular}{|c|c|c|c|c|c|c|c|c|c|}
\hline \multirow[b]{3}{*}{$\begin{array}{l}\text { Pair } \\
1\end{array}$} & & \multirow[b]{2}{*}{ Mean } & \multirow{2}{*}{$\begin{array}{c}\text { Std. } \\
\text { Deviation }\end{array}$} & \multirow{2}{*}{$\begin{array}{l}\text { Std. Error } \\
\text { Mean }\end{array}$} & \multicolumn{2}{|c|}{$\begin{array}{l}95 \% \text { Confidence } \\
\text { Interval of the } \\
\text { Difference }\end{array}$} & \multirow[b]{2}{*}{$\mathrm{T}$} & \multirow[b]{2}{*}{$\mathrm{df}$} & \multirow{2}{*}{$\begin{array}{c}\text { Sig. } \\
(2- \\
\text { tailed) }\end{array}$} \\
\hline & & & & & Lower & Upper & & & \\
\hline & $\begin{array}{l}\text { Nilai_Pretest_Keterampilan_Menyimak_dan_Berbicara } \\
\text { _Secara_Terpadu } \\
\text { Nilai_Postest_Keterampilan_Menyimak_dan_Berbicara } \\
\text { _Secara_Terpadu }\end{array}$ & -7.526 & 2.894 & .664 & -8.921 & -6.132 & -11.337 & 18 & .000 \\
\hline
\end{tabular}

Tabel 6. Hasil Uji Hipotesis Keeterampilan Menyimak dan Berbicara Secara TerpaduPaired Sample Statistik

\begin{tabular}{|c|c|c|c|c|c|}
\hline \multicolumn{6}{|c|}{ Paired Samples Statistics } \\
\hline & & Mean & $\mathrm{N}$ & Std. Deviation & $\begin{array}{c}\text { Std. Error } \\
\text { Mean }\end{array}$ \\
\hline \multirow[t]{2}{*}{ Pair 1} & Nilai_Pretest_Keterampilan_Menyimak_dan_Berbicara_Secara_Terpadu & 68.42 & 19 & 3.791 & .870 \\
\hline & Nilai_Postest_Keterampilan_Menyimak_dan_Berbicara_Secara_Terpadu & 75.95 & 19 & 5.233 & 1.201 \\
\hline
\end{tabular}

Berdasarkan Tabel 6 diperlihatkan hasil ringkasan statistik dari kedua sampel atau data pre -test dan pos -test. Nilai rata-rata pre-test keterampilan menyimak yakni 68.42 lebih kecil dari nilai rata-rata pos-test keterampilan menyimak, yakni 75.95 dengan jumlah responden atau peserta didik dijadikan sampel sebanyak, 19 peserta didik. Hal ini mengindikasikan bahwa penerapan metode storytelling berbantuan LCD proyektor secara baik, dan benar berpengaruh terhadap keterampilan menyimak dan berbicara secara terpadu peserta didik.

\section{c. $\quad$ Pengaruh Penerapan metode storytelling berbantuan proyektor terhadap keterampilan menyimak peserta didik SDN 64}

Malaka

Berdasarkan hasil penelitian didapatkan rata- rata nilai pretest 66,63 dan rata-rata nilai posttest sebeesar 72,11 yang berarti terjadi, pengaruh signifikan. Peningkatan keterampilan menyimak, yang terjadi pada kelas V SDN 64 Malaka sejalan dengan pendapat para ahli. Salah satu diantaranya, menurut Tarigam (2008) mempergunakan istilah "Seeing is to Hearing, same as Observing is to Listening as Reading is to Auding" yang terjemahaannya yaitu melihat untuk mendengar maka mengamati untuk mendengarkan sertamembaca, untuk menyimak. Penggunaan metode storytelling berhasil jika pendengar mampu menangkap jalan cerita, dan merasa terhibur, selain itu pesan moral dalam cerita juga diperoleh (Agus, 2010).

Menurut (Yudha, 2007) berbicara mengenai storytelling, sungguh banyak manfaatnya. Tak hanya bagi anak- anak, tetapi juga bagi orang-orang yang mendongengkannya. Dari proses storytelling kepada anak ini banyak manfaat yang dapat dipetik, seperti halnya orang dewasa, anak-anak, memperoleh pelepasan emosional melalui pengalaman fiktif, tapi yang tidak pernah m ereka alami dalam kehidupan nyata. Storytelling ternyata merupakan salah satu cara, yang efektif untuk mengembangkan aaspek-aspek kognitif (pengetahuan), afektif (perasaan), sosial, dan aspek konatif (penghayatan) anakanak. Banyak sekali maanfaat yang bisa kita peroleh melalui dongeeng antara lain:

a) Penanaman nilai-nilai

Storytelling meerupakan sarana untuk "mengatakan tanpa mengatakan", maksudnya storhytelling dapat menjadi sarana untuk mendidik tanpa perlumenggurui. Pada saat mendengarkan dongeng, aneak-anak dapat menikmati cerita dongeng yang disampaikan sekaligus memahami nilai -nilai / pesan yang terkandung dari cerita dongeng tersebut tanpa perlu untuk diberi tahu secaraa langsung atau mendikte. Pendongeng hanya mendongengkan tanpa perlu menekankan / membahas tersendiri mengenai nilai- nilai yang terkandung dalam cerita dongeeng tersebut.

b) Mampu melatih daya konsentrasi

Storytelling sebagai salah satu media informasi dan komunikasi yang digemari anak-anak, melatih kemaampuan mereka ,dalam memusatkan perhatian, untuk beberapa saat terhadap objek tertentu. Ketika seorang anak sedang asyik, mendengarkan dongeng, biasanya mereka tidak ingin di ganggu. Hal ini menunjukkan bahwa anak sedang berkonsentrasi mendngarkan dongeng.

c) Mendorong anak mencintai buku dan merangsang minat baca anak. 
Storytelling dengan media buku atau membacakan cerita kepada anak-anak ternyata mampu mendorong anak untuk mencintai bukudan gemar membaca. Anak dapat brbicara dan mendengar sebelum ia belajar membaca. Tulisan merupakan sistem sekunder bahasa, yang pada awal membaca, harus dihubungkan dengan bahasa lisan. Oleh karena itu, pengmbangan sistem bahasa yang baik, sangat penting untuk mempersiapkan anak belajar membaca. Storytelling dapat menjadi contoh yang efektif bagi anak mengenai cra membaca. Storytelling dengan media buku dapat menjadi stimulasi yang efektif, karena pada saat itu minat baca, anak mulai tumbuh.

Penggunaan metode story telling berbantuan proyektor membuat peserta didik lebih memperhatikan materi yang disampaikan, untuk mengurangi tingkat kejenuhan, peserta didik karena guru bias menampilkan cerit dongeng dengan video yang telah disiapkan guru.

d. $\quad$ Pengaruh Penerapan metode storytelling berbantuan proyektor terhadap keterampilan berbicara peserta didik SDN 64

Malaka

Berdasarkan hasil penelitian didaptkan rata-rata nilai pre-test sebesar 64,11 dan rata-rata nilai postest sebesar 73,53 yang berarti terjadi pengaruh signifikan. Peningkatan keterampilan menyimak, yang terjadi pada kelas V SDN 64 Malaka sejalan dengan pendapat para ahli. Salah satu diantaranya Iskandar wassid \& Dadang (2011) keterampilan berbi cara merupakan keterampilan mereproduksi, arus sistem bunyi arttikulasi untuk menyampaikan kehendak, kebutuhan perasaan, keinginan kepada orang lain.

Metode story telling menurut Nurbiana dkk (2005) suatu kegiatan yang dilakukan seseorang secara lisan kepada orang lain dengan alat / tanpa alat tentang, apa yang harus disampaikan dalam bentuk pesan, informasi atau hanya sebuah dongeng yang untuk di dengarkan dengan cara menyenangkan, karena orang yang menyajikan cerita tersebut menyampaikannya dengan menaik. Pengguna metode story telling berbantuan LCD Proyektor membantu peserta didik, melihat secara langsung dongeng yang diceritakan dan membuat ceriita dongeng tersebut terlihat menarik, memberikan dampak positif terhadap peserta diidik.

e. $\quad$ Pengaruh Penerapan metode storytelling berbantuan proyektor terhadap keterampilan menyimak dan berbicara secara terpadu peserta didik SDN 64 Malaka

Keteraampilan menyimak dan keterampilan berbicara secara terpadu saling berkaitan. Keterampilan menyimak peserta didik untuk menyampaikan makna dari isi yang dilihatnya dari LCD Proyaektor dengan dari hasil menggunakan keterampilan berbicara.

Dari hasil penelitian nilai rata-rata pretest sebesar 68,42 dan rata-rata postest 75,95 yang berarti terjadi pengaaruh. Peningkatan keterampilan menyimak dan keterampilan berbicara secara terpadu memiliki kesamaan. Di mana kesamaan ini ditunjukkan pada proses komunikasi, yang terjadi ketika seorang menyimak harus ada bahan yang disimak, yaitu pembiicara. Sebaliknya jika seorang berbicara, dia menuntut harus ada yang menyimak pembicaraannya.

Bila kita analisis "suatu peristiwa bahasa" atau "a language event" yang terjadi antara sang pembicara (speaker) dan sang penyimak / pendengar (listener/ hearer), terlihatlah seperti yang di gambarkan pada gambar berikut Tarigan dalam (Asdar, 2015).

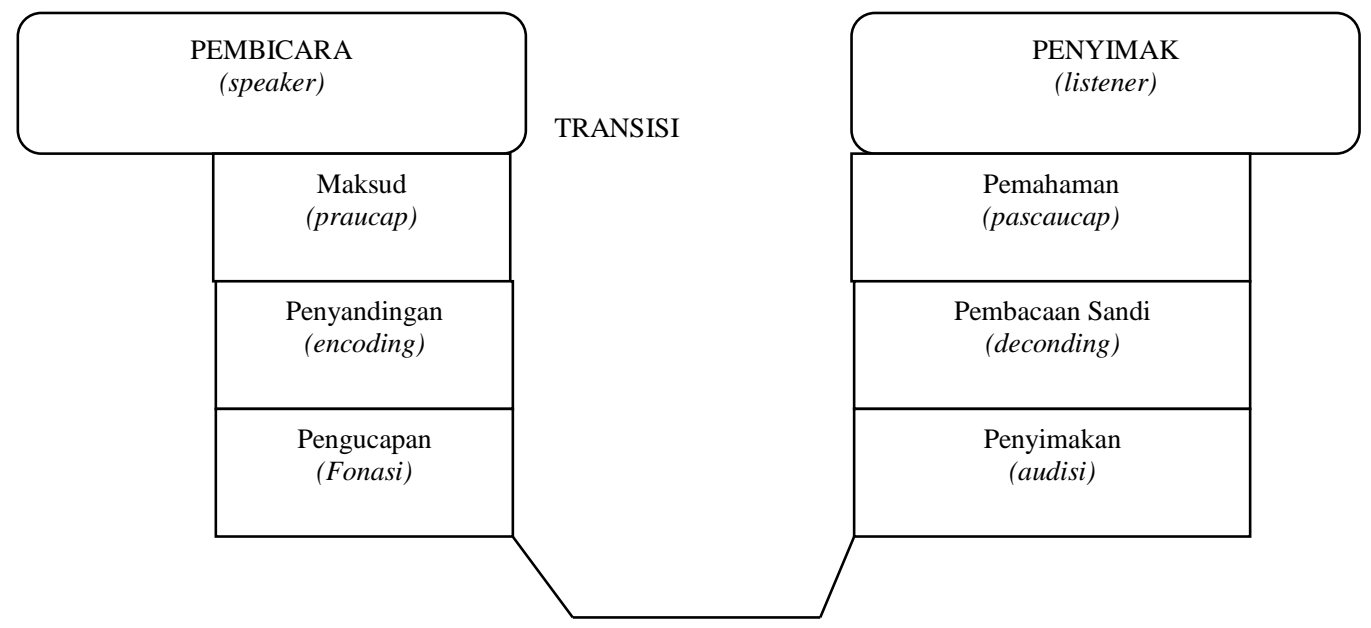

Gambar 2 Interkasi Sang Pembicara (speaker) dan Sang Penyimak /Pendengar (listener/ hearer

Berdasarkan hasil observasi awal, yang dilakukan peneliti yang pernah dilakukan (Arianto, 2018), faktor yang menyebabkan hasil belajar bahasa Indonesia, khususnya aspek menyimak, serta berbicara rendah umumnya adalah rendahnya kemampuan siswa dalam memahami, materi pembelajaran, kurangnya kemampuan siswa dalam mengungkapkan kembali dari hasil simakannya, melalui berbicara, dan motivasi belajar siswa rendah. Hal ini disebabkan, belum optimalnya usaha yang dilakukan guru, untuk membantu kesulitan belajar siswa, kurangnya variasi metode mengajar yang digunakan guru, untuk memotivasi belajar siswa di kelas. Peserta didik saat menyimak bacaan, yang dibacakan guru hanya mengantuk, bosan bahkan peserta didik, kadang malu atau ragu-ragu setelah guru memberikan kesempatan, untuk berbicara menceritakan ulang, tentang materi yang disimak dari bacaan yang dibacakan guru.

Oleh karena itu, guru harus menggunakan metode yang tidak membosankan karena guru hanya menggunakan metode ceramah, sehingga anak-anak merasa bosan dan tidak tertarik belajar serta masih jarang, menggunakan metode Storytelling berbantuan LCD proyektor. Metode Storytellingberbantuan proyektor baik digunakan dalam pembelajaran bahasa Indonesia materi aspek ket erampilan menyimak dan membaca karena peserta didik akan terfokus, tidak bosan, serta mengantuk. 
Dengan menggunakan metode storytelling, pembelajaran lebih modern srtamengenalkan peserta didik teknologi yang meningatkan pada perkembangan ilmu pengetahuan di era globalisasi.

\section{Kesimpulan dan Saran}

Hasil penelitian dapat disimpulkan terdapat pengaruh dengan menggunakan metode storyctelling berbantuan proyektor terhadap keteramcpilan menyimak peserta didik SDN 64 Malaka yang ditunjukkan dengan hasil statistik deskriptif, diketahui bahwa rata- rata hasil nilai pre-test keterampilan menyimak yaitu 66,63, sedangkan untuk rata-rata pos-test keterampilan menyimak yaitu 72.11, dengan demikian dapat disimpulkan bahwa nilai pos- test lebih tinggi dari nilai pre- test. Oleh kareena itu dapat disimpulkan bahwa terdapat pengaruh penerapan metode story telling berbantuan LCD proyektor terhadap keterampilan meenyimak peserta didik SDN 64 Malaka. Terdapat pengaruh dengan menggunakan metode story telling berbantuan proyektor terhadap keeterampilan berbicara peserta didik, SDN 64 Malaka yang ditunjukkan dengan hasil statistik deeskriptif diketahui bahwa rata-rata hasil Nilai pre -test keteerampilan berbicara yaitu 64.11, sedangkan untuk rata-rata postest keterampilan berbicara yaitu 73.53, dengan demikian dapat disimpulkan bahwa nilai pos-test lebih tinggi dari nilai pre test. Oleh karena itu dapat disiimpulkan bahwa terdapat pengaruh penerapan metode story telling berbantuan LCD proyektor terhadap keterampiilan berbicara, peserta didik SDN 64 Malaka. Terdapat pengaruh dengan menggunakan metode storytelling berbantuan proyektor terhadap keterampiilan menyimak, dan berbicara secara terpadu peserta didik SDN 64 Malaka yang ditunjukkan dengan hasil statistik deskriptiif diketahui bahwa rata-rata hasil nilai pre-test keterampilan menyiimak, dan berbicara secara terpadu yaitu 68.42, sedangkan untuk rata-rata pos-test keterampilan menyimak, serta berbicara secara terpaadu yaitu 75.95, dengan demikian dapat disimpulkan bahwa nilai pos- test lebih tinggi dari nilai pretest. Oleh karena itu dapat disimpulkan bahwa terdapat pengaruh penerapan metode storytelling berbantuan LCD proyektor terhadap keterampilan menyimakserta berbicara secara terpadu peserta didik SDN 64 Malaka. Disarankan siswa seharusnya berlatih, untuk meningakatkan keterampilan menyimak, keterampilan berbicar yang dapat dilakukan dengan cara mendengarkan berita, dan cerita-cerita. Kemudian siswa dapat melatih menuliskan inti cerita, serta unsur-unsur yang didengar. Kepada pendidik atau guru seharusnya menggunakan metode pembelajaran dengan bantuan media, yang telah disediakan oleh piihak sekolah maupun media yang dibuat sendiri oleh guru seperti halnya media LCD proyektor. Karena kreatiifitas guru, dalam mengajar sangatlah mempengaruhi hasil belajar siswa. Peneliti yang lain yang ingin melakukan penelitian yang serupa, agar lebih mengembangkan lagi penelitian seperti ini, sehiingga akan menghasilkan inovasi-inovasi baru dalam pembelajaran aspek keterampilan berbahasa khususnya keterampiilan menyimak dan berbicara.

\section{Daftar Pustaka}

Agustina,susanti. 2008. Meendongeng sebagai Energi Bagi Anak. Jakarta: Rumah Ilmu Indonesia.

Arianto. 2018. Model Pembeelajaran Terpadu untuk Meningkatkan Keterampilan Menyimak dan Berbicara. Kendari.

Azies \&Alwa silah. 2000. Pengajaran Bahasa Koomunikatif. Bandung: Remaja Rosdakarya.

Depdiknas .2003. Undang-undang RI No.20 tahun 2003.tentang sistem pendidikan nasional.

Dipalaya, T. (2020). Field Experience Practices Based Lesson Study (Ls) To Improve Students Communication Skills And Collaboration. Klasikal: Journal Of Education, Language Teaching And Science, 2(1), 48-62.

Jainuddin, J. (2019). Peningkatan Hasil Belajar Matematika Melalui Latihan Menyelesaikan Soal Secara Sistematis Pada Siswa Kelas XI. IPA1 SMA Negeri 2 Sungguminasa. Klasikal: Journal Of Education, Language Teaching And Science, 1(3), 44-52.

Jainuddin, J., \& Sirajuddin, S. (2020). Pengaruh Minat dan Kedisiplinan Siswa dengan Gaya Kognitif Field Indefendent terhadap Hasil Belajar Matematika Siswa SMK Farmasi Yamasi Makassar. Delta-Pi: Jurnal Matematika dan Pendidikan Matematika, 9(2).

Majid, Abdul. 2014. Pembelajaran tematik Terpadu. Bandung: Remaja Rosdakarya.

Putri, Delia \& Elvina. 2019. Keterampilan Berbahasa di Sekolah Dasar Melalui Metode Game’s. Penerbit Qiara Media.

Rahayu, Aprianti Yofita. 2013. Menumbuhkan Kepercayaan Diri Melalui Kegiatan Bercerita. Jakarta: PT Indeks.

Tarigan, Henry Guntur. 2008. Menulis sebagai Suatu Keterampilan Berbahasa. Bandung: Angkasa. 